\title{
ELEKTROMOS GÉPJÁRMUUVEK SZENZORHÁLÓZATÁNAK FELTÉRKÉPEZÉSE ÉS BIZTONSÁGI ELEMZÉSE
}

\section{MAPPING AND SECURITY ANALYSIS OF SENSOR NETWORK FOR ELECTRIC VEHICLES}

\author{
Tuloki Szilárd ${ }^{1}$, Nagy István ${ }^{2}$ \\ ${ }^{1}$ Óbudai Egyetem, Bánki Donát Gépész és Biztonságtechnikai Mérnöki Kar, H-1034 \\ Budapest, Bécsi út 96/B; Tel.: +36-1-666-5300, tuszilard@gmail.com \\ ${ }^{2}$ Óbudai Egyetem, Bánki Donát Gépész és Biztonságtechnikai Mérnöki Kar, H-1081 \\ Budapest, Népszínház u. 8.; Tel.: +36-1-666-5366 nagy.istvan@bgk.uni-obuda.hu
}

\begin{abstract}
Today's vehicles are becoming more and more complex, becoming more and more complicated in order to meet the ever increasing safety and comfort requirements. Most people usually do not consider the car sitting in their driveway to be on the leading edge of new technology. However, for most people, the personal automobile has now become their initial exposure to new intelligent computational technologies such as fuzzy logic, neural networks, adaptive computing, voice recognition and others. This paper tries to explore the sensory-network of the electric vehicles and analyse it from a security, reliability perspective.
\end{abstract}

Keywords: sensory network, reliability, on-board control system.

\section{Összefoglalás}

Napjaink jármüvei egyre összetettebbé, egyre bonyolultabbá válnak annak érdekében, hogy kielégítsék az egyre növekvő biztonsági és kényelmi követelményeket. A legtöbb ember észre sem veszi, hogy a bejárat előtt álló kocsija az új technológia élvonalába tartozik. Továbbá a legtöbb ember számára a személygépkocsi az első eszköz, ahol új intelligens számítástechnikai technológiával, mint az adaptív irányítás, hangfelismerés stb., találkozik. Ennek érdekében, már a hétköznapi életben fellelhető személygépkocsik is nagymértékben tartalmaz intelligens szenzorokat, melyek valamilyen hálózatban kapcsolódnak egymáshoz, illetve a fedélzeti processzorhoz. Ez a dolgozat ezt a szenzorrendszerhálózatot próbálja feltérképezni, majd biztonság szempontból elemezni.

Kulcsszavak: szenzorhálózat, megbízhatóság, fedélzeti irányító-rendszer.

\section{Bevezetés}

Az elektromos autók érzékelő rendszere belsö érzékelökre (pl. inkrementális kódolók, keréksebességérzékelők) és külső érzékelőkre (pl. kamerarendszer, GPS) osztható. Jelen cikkben a szenzorhálózatok redundanciájának kiaknázására összpontosítunk a térbeli interpoláció összefüggésében. A hálózat elosztott mintavételi rendszerként müködik, ahol az érzékelők rendszeres időközönként megvizsgálják a kívánt fizikai jelenségeket, pl. hőmérséklet, sebesség. Az autók számára a folyamatos biztonság, teljesítmény növelése, a környezeti hatások csökkentése, kényelem növelése érdekében folyamatosan növelni kell az autó elektronikus vezérlőegységei (ECU) közötti kommunikáció sebességét, mennyiségét és megbízhatóságát. Fejlett vezérlési és biz- 
tonsági rendszerek, -több érzékelőt, működtetőt és elektronikus vezérlő egységet kombinálva-, olyan szinkronizációt és teljesítményt igényelnek, amik felülmúlhatják a jelenlegi sínrendszerek teljesítőképességét. A kommunikációs hálózatban a topológia kifejezés azt jelenti, hogy az eszközök hogyan vannak összekapcsolva a hálózatban. A hálózati topológiák alapvető típusai: Sín (Busz) Topológia, Csillag Topológia, Gyürü Topológia, Háló Topológia és Fa Topológia. A szenzoros rendszer elektromos eszközei többnyire a fa topológiát és a háló topológiát kombinálják, így a hibadiagnózis egyszerübb lehet. [1,2]

\section{Szenzor-hálózat topológia}

A fa topológiában csak egy útvonal található a hálózat bármelyik két csomópontja között. Ezt nevezik hierarchikus topológiának is, amelynek legalább három szintje van a hierarchiában [2,3].
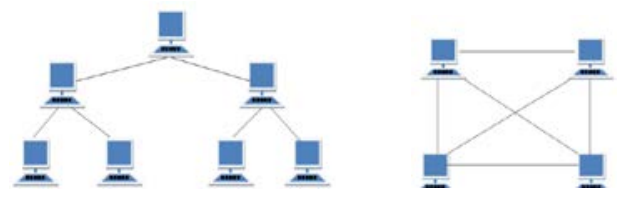

1. ábra. Fa és Háló Topológia

A háló topológiában a csomópontok vagy utasítások között pont-pont „point to point" összeköttetés van. Ez lehetővé teszi a folyamatos összeköttetéseket és a „szakadt” vagy blokkolt útvonalak újrakonfigurálását a csomópontról a csomópontra történő ugrással a rendeltetési helyig. [2,3]

\section{Lehetséges fedélzeti vezérlő- eszközök, processzorok}

\subsection{GPP}

Az általános célú processzorokat (General Purpose Processor) több alkalmazás végrehajtására és több feladat elvégzésére tervezték. Sajnos meglehetősen drágák lehetnek, különösen olyan kis eszközök szá- mára, amelyeket speciális feladatok elvégzésére terveztek.

\subsection{ASIP}

Az alkalmazás specifikus processzorok (Application Specific Processor) megoldást jelentenek a nagy teljesítményű és költséghatékony processzorok számára. Alkalmazás-specifikus processzorok életünk részévé váltak, és szinte minden olyan eszközben megtalálhatóak, amiket napi rendszerességgel használunk: TV, GPS, mobiltelefonok. Az alkalmazás specifikus processzor ötvözi a nagy teljesítményt, az alacsony költségeket és az alacsony fogyasztást. [4]

\subsection{ASIC}

A GPP-hez képest az ASIC (Application Specific Integrated Circuit - alkalmazás alapú IC-k) alapú rendszerek jobb teljesítményt és áramfogyasztást kínálnak, de a rugalmasság és a bővíthetőség rovására. Noha nehéz használni az ASIC-t más feladatokhoz, mint amire tervezték, de lehetséges a GPP használata az ASIC mellett ugyanazon a rendszeren belül is általánosabb, kevésbé igényes feladatokra.[4]

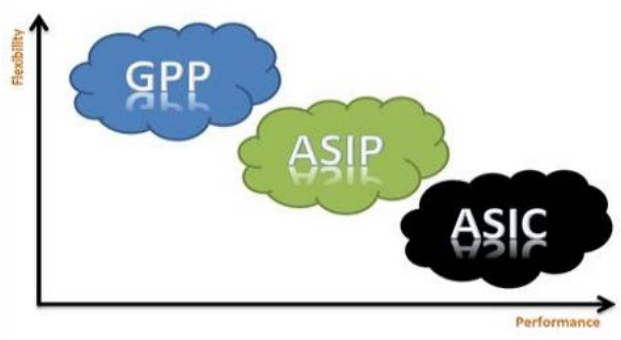

2. ábra. Processzorok összehasonlítása a teljesítmény és rugalmasság terén[4]

\section{Kommunikációs protokollok}

A kommunikációs protokollokban a legtöbb gépjármü különböző típusú technológiákat alkalmaz. A legnépszerübb ezek közül az univerzális aszinkron adó-vevő (UART), a soros RS-232, soros perifériaillesztő (SPI), integrált áramkörök közötti 
$\left(\mathrm{I}^{2} \mathrm{C}\right)$, CAN, CANOpen, helyi összeköttetés hálózata (LIN), média orientált rendszer (MOST), FlexRay. Az általunk vizsgált rendszeren CAN és CANOpen hálózatok vannak jelen.

\subsection{CAN}

A CAN-buszt a BOSCH fejlesztette ki, mint „multi-master” üzenetszóró rendszer, melynek maximális jelátviteli sebessége 1 megabit/másodperc (Mbps). Ellentétben a hagyományos hálózatokkal (USB, Ethernet), a CAN hálózat nem küld nagy üzenetblokkokat, hanem sok rövid üzenetet, például hőmérsékletet vagy fordulatszám (RPM), és ez biztosítja az adatok egységességét a rendszer minden csomópontjában. Eredetileg az autóipar számára fejlesztették ki, hogy lecserélje a bonyolult kábelkötegeket egy két vezetékes rendszerre. Ezáltal a rendszer nagyfokú elektromágneses interferencia ellenállású és az adatok hibáinak önmeghatározására és az adat hibák javítására képes. [5]

\subsection{CANOpen}

Amikor a nagyfeszültség zavarja az adatátvitelt, elkülönítésre van szükség. A CANopen lehetővé teszi a csomópontok közötti közvetlen „peer-to-peer” adatcserét szervezett és szükség esetén, determinisztikus módon. A CANopen által meghatározott hálózati menedzsment funkciók egyszerüsítik a projekttervezést, a végrehajtást és a diagnózist a hálózati indítás és a hibák kezelésének szabványos mechanizmusaival. A CANopen támogatja mind a ciklikus, mind az eseményvezérelt kommunikációt. Ez lehetővé teszi a buszterhelés minimalizálását, de továbbra is rendkívül rövid reakcióidőt tart fenn. Viszonylag alacsony átviteli sebesség mellett nagy kommunikációs teljesítmény érhető el, csökkentve ezzel az elektromágneses interferenciákat (EMI) és a kábelköltségeket. [6]

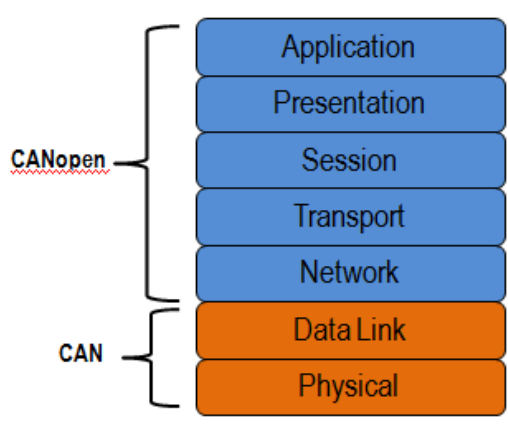

3. ábra. CAN és CANopen az OSI modellben [6]

\subsection{Jármű kommunikáció}

Alapvetően egy jármű kommunikációs rendszere három fö részre osztható:

- Gépjármüben történő kommunikáció: a sávszélesség növekvő igénye, valamint a teljesítmény, a költségek és a megbízhatósági követelmények változatossága a jármüvekben használt hálózatok diverzifikációjához vezet. Különböző hálózatok különböző követelményeket, sávszélességet igényelnek (pl. keréknyomás érzékelö);

- Jármüvek közötti kommunikáció: olyan rendszer, melynek célja az alapvető biztonsági információk átadása a jármüvek között, megkönnyítik a gépjármüvezetőknek a közelgő balesettel kapcsolatos figyelmeztetéseit;

- Jármü - mühold kommunikáció: új technológia, amely új lehetőségeket kínál a jármüvek számára. Mint például a sürgősségi vészhívók, a jármüvek nyomon követése vagy a forgalom nyomon követése.

\section{Hiba terjedésének elemzése elektromos jármúvek érzékelő hálózatában}

A keréksebesség-érzékelő esetén az alábbi hálózati kapcsolatot fedeztük fel. 


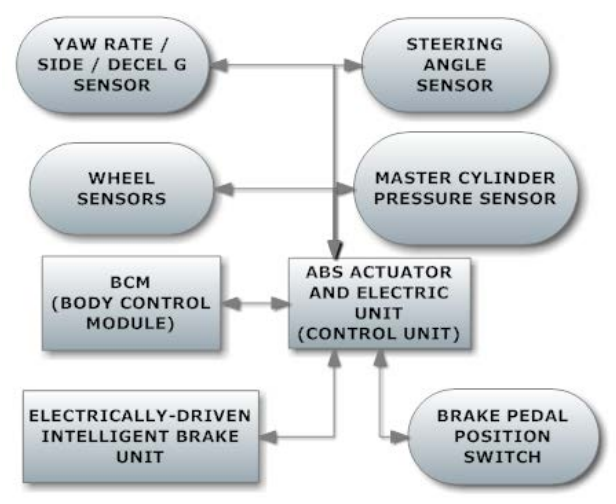

4. ábra. Keréksebesség érzékelö kapcsolatok

\subsection{Az AMR keréksebesség-szenzor ismertetése}

Az érzékelés során az anizotropikus mágneses ellenállást (AMR) alkalmazza. A magnetostrikció ferromágneses anyagok tulajdonsága, ami magnetizáció által változtatja az alakját és a dimenzióját. Mivel az MR hatás nem képes közvetlenül mérni a forgási sebességet, az impulzus keréknek (kódtárcsa) képesnek kell lennie a mágneses mező megváltoztatására. A keréksebesség-alkalmazásokhoz kétféle kódtárcsa használható: mágnesezett és ferromágneses. A mágnesezett kódolók saját mágneses mezővel rendelkeznek, míg a ferromágneses jeladók csak egy meglévő mágneses mezőt befolyásolnak - ezt az érzékelőn alkalmazott mágnes generálja [7]

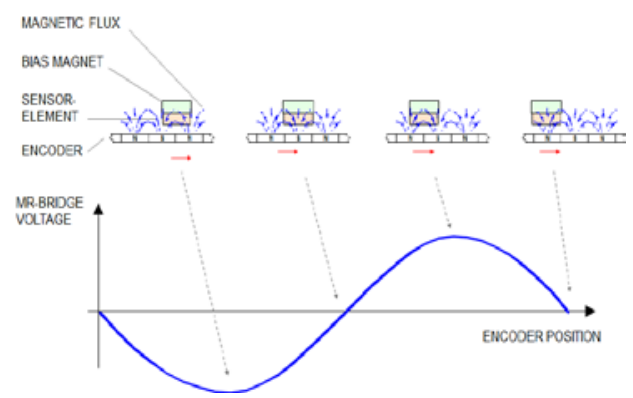

5. ábra. $A z A M R$ híd kimeneti jele mágneses jeladóval

\subsection{Lehetséges hibák}

$\mathrm{Az}$ 5. ábrán mindegyik érzékelö képes hibaüzenetet küldeni, és a vezérlőegységek képesek egy másik, rendszer hibaüzenetet küldeni, amely segít a hiba forrásának megállapításában. A kerékérzékelők esetén 4 különböző hibát kapunk, egyenként minden egyes kerékre. A lehetséges hibaforrások, amiket elemezni kell: az analóg jel küszöbölési szintje, A/D átalakítás, és a jelterjedés (itt a zavarás és a terjedési sebesség ellenőrzése a fontos). A kérdés, hogy menynyire valós-idejü az aktuális hiba kezelése.

\section{Köszönetnyilvánítás}

A kutatást a Magyar Állam és az Európai Unió támogatásával, az Európai Szociális alap társfinanszírozásával megvalósuló EEFOP 3.6.2-16-2017-00016: “Autonóm jármüvek dinamikája és irányítása az automatizált közlekedési rendszerek követelményeinek szinergiájában” project támogatta.

\section{Szakirodalomi hivatkozások}

[1] Culler, D., Estrin D., \& Srivastava, M. B. (2004). Overview of sensor networks. in Computer, August 2004.

[2] National Instruments: FlexRay Automotive Communication Bus Overview, Publish Date: Srp 24, 2016;

[3] Analytical study of different network topologies, International Research Journal of Engineering and Technology (IRJET) e-ISSN: 2395-0056,

[4] Application specific processors ECE/CS 570 project final report, Yousef Qasim Pradyumna, Janga Sharath Kumar, Hani Alesaimi,

[5] Introduction to the Controller Area Network (CAN), Application report, Texas Instrumens, SLOA101B August 2002 Revised May 2016

[6] National Instruments, The Basics of CANopen, Publish Date: Srp 21, 2013 